\title{
Real Lives and Lost Lives: Making Sense of 'Locked in' Responses to Intimate Partner Homicide
}

\author{
Sandra Walklate ${ }^{1}$ (D) Anna Hopkins ${ }^{2}$
}

Received: 31 October 2018 / Accepted: 1 March 2019 / Published online: 30 March 2019

(C) The Author(s) 2019

\begin{abstract}
The problem of intimate partner homicide is featuring increasingly on national and international policy agendas. Over the last 40 years, responses to this issue have been characterised by preventive strategies (including 'positive' policing; the proliferation of risk assessment tools, and multi-agency working) and post-event analyses (including police inquiries and domestic homicide reviews). In different ways, each of these responses has become 'locked in' to policies. Drawing on an analysis of police inquiries into domestic homicides in England and Wales over a 10-year period, this paper will explore the nature of these 'locked in' responses and will suggest that complexity theory offers a useful lens through which to make sense of them and the ongoing consistent patterning of intimate partner homicide more generally. The paper will suggest this lens in embracing what is known and unknown affords a different way of thinking about and responding to this problem.
\end{abstract}

Keywords Intimate partner homicide $\cdot$ Complexity theory $\cdot$ Preventing violence against women

\section{Introduction}

How a state responds to femicide is of international interest (Dawson 2016). It is evident different countries are developing ways of responding to this issue from the introduction of specific legal offences of femicide (de Avila 2018) or Domestic Violence Disclosure Schemes (Fitz-Gibbon and Walklate 2017) to focusing energy on specialised police response units (see for example, Regoecz and Hubbard 2018; Segrave et al. 2016). This paper focuses attention on

Sandra Walklate

S.L.Walklate@liverpool.ac.uk

Anna Hopkins

annahopkins22@hotmail.com

1 Department of Sociology, Social Policy and Criminology, School of Law and Social Justice, University of Liverpool, Eleanor Rathbone Building, Bedford Street South, Liverpool L69 7ZA, UK

2 Edge Hill University, Ormskirk, Lancashire, UK 
the efficacy of these policy responses paying particular attention to one feature of femicide: intimate partner homicide (IPH).

The UNODC (2013) reports that $79 \%$ of all homicide victims globally are male with $95 \%$ of perpetrators globally also being male. Despite this pattern in Asia, Europe and Oceania, those most at risk from IPH are women aged 30 and over. This is a remarkably consistent statistic irrespective of region (see inter alia Brennan 2016 for the U.K., for Europe see Corradi and Stokl 2014; Cussen and Bryant 2015 for Australia; Smith et al. 2014 for the USA; CFOJA 2018 for Canada; Eguizábal et al. 2016 for Latin America, and UNODC 2013). Such statistics have led to an increasing acknowledgement of the problem of IPH, its costs, and its consequences for women and children (World Health Organisation 2013; Fitz-Gibbon et al. 2018). Whilst there are ongoing debates concerning the underlying causal mechanisms contributing to this phenomenon (from the presence/absence of gender equality in different societies to intrinsic and endemic patriarchal social relations and attitudes), there are remarkably similar characteristics in global policy responses to it. Put simply, these responses fall into two categories: preventive strategies (including 'positive' policing, the deployment of risk assessment tools, and multi-agency/partnership working); and post-event analyses designed to inform and improve such preventive strategies (including police inquiries and domestic homicide reviews). Set against these developments, this paper emanates from a smallscale study of Independent Police Complaints Commission Reports (now known as the Independent Office for Police Conduct) on IPH in England and Wales over a 10-year period. Its purpose is to explore the efficacy of the policy responses outlined above in the light of this empirical data and, on the basis of this data and other widely available empirical work, suggest that it may be apposite to develop some different conceptual thinking concerning how best to respond to IPH.

In order to do this, the paper falls into four parts. The first part will present the key findings of the study on which this paper is based. The second part will review the main policy responses to IPH which have emerged over the last 40 years. This will offer an overview of the documented strengths and weaknesses of these policy responses in relation to the data set presented here and in relation to the patterning of IPH highlighted above. The third part of this paper will reflect upon the question why: why does this pattern of IPH, both locally and globally, remain intransigent to change in the face of policies enacted as a response to it? This part of the paper will explore an answer to this question through the lens of complexity theory. The fourth and final part of this paper will reflect on the extent to which this lens might impact upon criminology, and the policy responses to, the lives lost as a result of intimate partner homicide.

\section{The 'Real Lives, Lost Lives' Project}

This small scale study was funded by the School of Law and Social Justice Research Development Fund at the University of Liverpool in 2017. The purpose of the study was to conduct a thematic analysis of Independent Police Complaints Commission (IPPC) Reports for England and Wales from 2005 to 2015 relating to IPH and available as public documents. As individual documents, these reports are frequently referred to in media and other sources when demands for a 'post-mortem' on individual cases are made, especially when such deaths have occurred after contact with the police. As sources of data in relation to individual cases, they 
are both contested and problematic (see Baker 2016) and are clearly reports concerned to address police failings. However, such reports have rarely been used systematically; that is, as a data set documenting a series of recurring events rather than one-off incidents. The purpose of this study was to do this with a view to informing understandings of the possible tensions between what has been referred to as 'positive' policing and the messiness of women's real lives. Fifteen publicly available reports from 2005 to 2015 from 11 different police forces in England and Wales were analysed thematically following the guide offered by Braun and Clarke (2006). This process identified a number of recurrent themes across all of the incidents brought to the attention of the IPCC. Table 1 offers an overview of these themes and the rate of their occurrence.

These commonly recurring themes were found in all of the reports analysed. Obviously listing and itemising them, as in the Table 1, masks the complexity of the particular individual situations each report addressed. Nonetheless, what this table does reveal is a recurring consistency in the kinds of failures occurring across a range of different incidents over time and in different police force areas. Failures of this kind do, of course, manifest themselves differently in different cases and to different degrees. The following two vignettes offer a more detailed illustration of this.

\section{Vignette 1}

In this case, the police had on record 17 separate events between 12 January 2010 and 5 January 2012 relating to the woman who was murdered. This woman separated from her husband in 2011 and she lived alone. On 7 December 2011, she made a report to the police alleging her husband had assaulted her by putting his hands around her throat and tried to strangle her. She went on to make four further reports the police regarding breach of his bail conditions between 11 December and 30 December 2011. On Thursday, 5 January 2012, he left notes outside her home suggesting he was to take his own life. A police incident was created as officers made unsuccessful efforts to trace him. About $6.10 \mathrm{pm}$ that evening, he forced his way into her home and stabbed her several times. He was later convicted of her murder. The police reports suggest this couple engaged in a chaotic lifestyle with both parties depending on alcohol heavily throughout the incidents. This appeared to be detrimental towards the victim in terms of her reliability as a potential witness and resulted in CPS not charging her abuser as a result of this. The presence of alcohol seems to inform a lack of positive action on the part of the police in relation to 12 of the incidents reported to them. On a number of occasions, there were

Table 1 IPPC reports: percentage occurrence of common themes of failure

\begin{tabular}{ll}
\hline Themes associated with police 'failures' & Percentage occurrence \\
\hline Lack of 'positive' action & $66 \%$ \\
Inappropriate risk assessment' & $53 \%$ \\
Failure to see the 'bigger picture' & $53 \%$ \\
Lack of adherence to force policy & $33 \%$ \\
Inaction in relation to threats to kill & $26 \%$ \\
No further action by the Crown Prosecution Service (CPS) & $26 \%$ \\
Inadequate training & $23 \%$ \\
\hline
\end{tabular}

${ }^{\text {a }}$ Most police forces in England and Wales use the DASH risk assessment tool with the exception of Merseyside where MERIT is used 
delays in the process of risk assessment. In total, 6 risk assessments were completed in this case: 2 assessed as standard risk, 2 as medium risk and 4 as high risk. None of this over the course of the time that the police had contact with this victim seemed to inform their response to her. Moreover, the chaotic lifestyle of both parties seemed to affect decisions made by the Crown Prosecution Service (CPS) with no evidence offered in the reports that they were adhering to a policy of positive action. When, on one occasion the victim retracted her complaint the CPS dropped the case even when independent witnesses and evidence of injury was available to support the prosecution. Yet, it is clear from the statements available in the IPCC Report that the victim was in fear of her husband. One incident reported, '[He] tried to strangle her, threatened to kill her and then threw her dog across the room. She made a statement of complaint saying, "I genuinely believed he would kill me and I think it is only a matter of time before he does kill me". Failure to see the 'bigger picture' is evident in this case. There was a lack of communication and policy practice between the police and CPS, between custody sergeants taking over shifts, between detective constables and inspectors and generally not focusing on the risk to the victim, and being over focused on risk to the offender in terms of the threatened suicide. The 'call handling' manager for the Force Contact Centre (FCC) later said the information concerning an 'ongoing' investigation and 'domestic abuse' markers were considered subordinate issues to the immediate concern for the safety of the offender. The IPCC Report clearly states that this was a mistake. At no point in this case did the police or the CPS consider alternative ways of supporting the victim and tackling the reported behaviour of the offender when there were strategies available for them to do so.

\section{Vignette 2}

This second case involved a young mother who was murdered in October 2010 in her home. Her assailant had an extensive criminal record and warnings on the Police National Computer for violence but he did not have any previous convictions for domestic abuse-related offences. Eleven separate incidents involving these two people were reported to police between 2008 and 2010. The IPCC Commissioner states:

In this case it is clear that a number of officers failed to perform to the level expected of them. This was borne of a lack of knowledge and a willingness to accept the word of a woman who had suffered years of abuse when she said she did not want or need their help. As a result basic actions that may have helped others see the full picture of her suffering were not completed. No consideration was given as to why [she] was reporting domestic abuse but then saying that she did not want police help. This was a young mother living in constant fear of a man for what must have felt like an eternity to her. Little thought was given finding a way to prosecute without the need to rely upon [her] as a witness. This is particularly pertinent as there were independent witnesses to some of the incidents. Not least, security guards who saw visible injuries on [her] heard [him] threaten to kill her and were present when he telephoned her and threatened to shoot her family with a gun. Sadly, this evidence which could and should have been obtained at the time was not obtained until after she had been murdered.

This case was also marked by poor risk assessment practices, poor internal police communications and failures on the part of the CPS. 
In many ways, none of the above is surprising, geographically unique to England and Wales, or to anyone who has been researching or working in this field in recent decades. Indeed from the case of Tracey Thurman in the USA in 1984, which sparked the embrace of mandatory arrest policies for domestic violence perpetrators in that country, to the case of Kelly Thompson in Melbourne 2014, which sparked public outrage, individual cases have repeatedly exposed the inadequacies of policing and criminal justice responses to violence against women. Thompson was killed by her former partner despite an intervention order against him (which had been breached on at least two occasions Gray 2016: 77) and in the 3 weeks prior to her death, she called the police on at least 35 occasions, having disclosed the violence she was experiencing to friends, neighbours and work colleagues, and made contact with a family violence outreach service (Percy 2015; Gray 2016, see also Fitz-Gibbon 2016). In the case of Tracey Thurman, whilst the violence she experienced did not result her death, it was marked by very similar patterns of behaviour to that reported in the case of Kelly Thompson and the patterns documented in Table 1. What is of interest therefore is the repeated nature of these recorded failures over time and across space despite the concerted efforts of policies and practices to do otherwise. In sum, many women in different parts of the world and at different times, as well as those in the small scale study reported on above, have been failed at multiple points in their interactions with the police and other agents of criminal justice processes. Thus, making sense of why this is the case is of interest not just for England and Wales but for other jurisdictions across the globe.

Of course, predicting fatal outcomes for intimate partner violence (IPV) is fraught with difficulties since less than half of such cases have prior contact with the police (Thornton 2017). Moreover, when they do have contact with the police, as Thornton (2017: 65) points out, in $89 \%$ of cases, she examined they were not assessed as high risk. Work by Bridger et al. (2017), using police data and information gleaned from domestic homicide reviews for England and Wales, suggest that there are greater possibilities of prediction (and thereby prevention) of IPH if more attention was paid to the suicidal tendencies of the prospective offender. This knowledge clearly did not have the desired effect in the first vignette cited above though it did afford a higher risk assessment for the perpetrator rather than the victim. From this example and the other data cited above, there are also evidenced and repeated difficulties in assessing and assigning appropriate levels of risk in these kinds of cases. Indeed, the relationship between such risk assessments and subsequent IPH is somewhat arbitrary (Westmarland 2011:300-301; see also Day et al. 2014) with risk assessment practices in general assuming a scalar view of violence in relationships which may or may not exist (see inter alia Johnson et al. 2017). Yet, the import of particular risk moments (like separation from a partner, as in both vignettes here; see also Dekeseredy et al. 2017) is quite well established though not necessarily fully acknowledged in practice. In addition, whilst it is possible, individual systems and/or risk assessment tools can contribute positively towards responding to IPV/IPH, combining these systems, as in multi-agency working, can also result in interruption, disjointedness and failures in appropriate communication and assessments. All of which are illustrated in the cases above (see also Dawson 2017). At the same time, the failure to read across what might be learned from the kinds of reports discussed here is also telling. Taken together, the findings from these reports point to a persistent focus on what could have or should have been done by criminal justice agencies in what are highly emotionally charged and messy situations for all the participants, including the criminal justice professionals. It is this ongoing focus on what is doable and actionable for criminal justice systems which informs the next part of this discussion. 


\section{Preventive Policy Responses: From Intimate Partner Violence to Intimate Partner Homicide}

In taking a closer look is taken at state responses to IPV/IPH, it is possible to discern a number of criminal justice strategies which have gathered momentum over the last 30 years or so. These policies share an underlying assumption that the prevention of IPV will lead to the prevention of IPH (see inter alia ARC 2016; DCHPI 2016). Such policies range from the pre-emptive (improving contact with the police, engaging in risk assessment, multiagency working and information sharing) to post-event analyses from which lessons might be learned (particularly current in this regard is the development of Domestic Homicide Reviews). Against this backcloth, it is important to note, as Iratzoqui and McCutcheon (2018: 147) suggest;

Within criminological research, domestic violence has been treated as a separate entity, because domestic violence is largely seen as a "uniquely female" phenomena, since females are overwhelmingly the victims of this form of violence, especially over time.

Leaving aside the considerable debate concerning the salience of gender in making sense of violence against women, it is without doubt that, for the most part, criminological research has treated such violence as separate and separable from the wider recourse to violence. Yet, it is also the case that use of violence by perpetrators (men) frequently cuts across the publicprivate, peace-time-war-time divide characterising much criminological research (see inter alia Barberet 2014; Braithwaite and D'Costa 2018). Such evidence notwithstanding, the policy domain following the academic lead separates off violence against women as in need of separate/different policy interventions. Taking this as a potentially problematic starting point, several of these policies are discussed in turn in what follows.

Since the seminal work of Sherman and Berk (1984) on the deterrent effects of arresting the perpetrators in incidents of domestic violence, there have been repeated efforts to engage in 'positive' policing strategies in cases of such violence. Indeed, despite the later refinement of these findings by the same researchers (Sherman et al. 1991), the focus on these kinds of interventions has continued unabated across the globe amounting to what Goodmark (2015) has called 'exporting without a licence'. In using this phrase, she is referring to both the shaky empirical foundations on which such policies are based and the belief that policies and practices developed in the USA will work elsewhere (see also Walklate and Fitz-Gibbon 2018). Indeed, many scholars have asked important questions about the capacity of the criminal justice system to protect and support women and children (Stanko 1995; Hirschel et al. 2007); it nevertheless remains the case police officers are important points of contact for many victims of IPV across the globe. Moreover, the focus on this moment of contact has been sustained, despite all the evidenced difficulties it can entail for the police. These difficulties range from victim-blaming to stereotyping, to poor understanding and training in relation to such violence. The focus on this policing moment has often been sustained in isolation both from the expectations associated with policework more generally and in isolation from responding to violence more generally. So much so Barlow and Walklate (2018) have suggested this kind of policy response has become a 'boundary object' (Star and Griesemar 1989). Such objects involve 'a community of interested parties who frame ways of thinking and doing about particular subjects, that also involve excluding other ways of thinking and knowing' (Barlow and Walklate 2018: 6). Features of such inclusion and exclusion are also found within the burgeoning influence of risk assessment tools. 
The use and deployment of risk assessment tools, not only for at risk offenders but also for at risk victims, has risen rapidly on policy and practice agendas. This is despite the fact that few of these tools have been subjected to empirical validation (McCulloch et al. 2016). Moreover, when they have been tested, research suggests a weak or modest predictive power (Medina et al. 2016), conflation of prevention and prediction (O’Malley 2006), with little attention paid to historical and social context (Cunneen 2014). In sum, such tools can deny the presence and influence of both structure and agency and embrace risk as a forensic, unifying and unified concept (Mythen 2014). When such tools are applied to women living with violence in all its forms (including threats to kill as illustrated in the data above), women's own knowledge of when the next act of violence is likely to occur can be erased yet this can be crucial to understanding their level of risk. Indeed, Smith et al. (2010: 27) suggest this form of intimate knowledge may be deeply embedded in their strategies for coping with 'battering' and 'include[s] family history of abuse, gender role socialisation, the attitude toward violence of the immediate and extended social network, and various characteristics of the abuse and abusive partner'. (See also inter alia Kirkwood 1993; Genn 1988). In addition, Day et al. (2014: 581) report:

There is some evidence to suggest that partner estimates of risk can also consistently predict future victimization, with approximately two thirds of victims correctly identifying their assessed level of risk.

However, the extent to which women's voices are actually heard in processes of risk assessment is moot, as illustrated in the cases above, alongside many others. Moreover, the uncritical embrace of risk embedded in such practices not only fails to capture the reality of people's/women's lives, it also embeds an understanding of risk in which risk is seen as the 'master key through which the most pressing social problems of the age can be unlocked' (Mythen 2014: 33). However, the extent to which this key is master in a global sense is open to debate (see inter alia Cunneen and Rowe 2015). It is at this juncture what De Sousa Santos (2014) might call the ghostly relationship between theory and practice emerges, echoing in a different way the problem of separation alluded to by Iratzoqui and McCutcheon (2018) cited earlier. The criminal justice practice of risk assessment, the wide range of tools available and their efficacy notwithstanding, aligned as it is to the criminological embrace of risk, raises the ghostly presence of criminology's origin stories (Carrington and Hogg 2017; Goodmark 2015). This spectral presence frames what is actionable and doable in responding to IPV/IPH: risk assessment. The presence of this bounded thinking in risk assessment tools in which risk is used as uniform, unifying and forensically, is almost palpable (Walklate 2018). Its import is profound since this understanding of risk is frequently shared between multi-agency partners.

Multi-agency responses to violence against women were centred by the Duluth Model developed in the USA in the early 1980s (Shepard et al. 2002). This approach put to the fore a whole community response to such violence. Over the course of time this has become more loosely interpreted as multi-agency partnership. These have grown in popularity in the UK and elsewhere and Robinson (2006) concludes they have been invaluable in enabling agencies to assist victims of domestic abuse more efficiently and in maximising their safety. However, more recent work in the UK criticises this approach for only focussing on high risk victims (Myhill and Hohl 2016). In addition, there are endemic concerns about initiatives such as these in terms of their ability to effectively engage with meaningful and appropriate information sharing on which their decisions might be based (see for example Stanley and Humphreys 
2014). These concerns include questions of terminology; whether or not all the partner agencies are actually talking the same language (Walby et al. 2017). Importantly intrinsic to the Duluth Model was a holistic approach to the problem of violence against women. This actually reaches beyond multi-agency partnership. Whilst successful information sharing and partnership working can lead to positive outcomes (Curtis et al. 2011), the partial embrace of a holistic approach as in multi-agency partnerships arguably affords the space for organisational interests to prevail over service delivery (Thompson 2013). As a result this can work against, for example, meaningful information sharing. Indeed, much of this kind of messiness occurred in just over one third of occasions in the cases discussed in Table 1. The complex nature of organisations and inter-organisational service delivery is re-visited below since this has also emerged as a recurrent issue in Domestic Homicide Reviews (DHR).

DHRs (in some jurisdictions also referred to as Fatality Reviews) first emerged in the early 1990s in San Francisco in the USA and have since become adopted in a range of jurisdictions from North America to Australia (see Dawson 2017). In some contexts, these reviews have been accompanied by the emergence of observatories which document women's deaths as a result of men's violence (in Canada and Portugal for example). Whilst these reviews may vary in structure, governance and practices, they share the common purpose of both calling to account and accounting for the nature of such deaths and how criminal justice (and other) responses might be improved in the light of their findings. In sum, they constitute a specifically focused form of partnership working. A recent assessment of the recommendations from DHRs conducted in England and Wales by the Home Office (2016) over a 4-year period found the following recurring problematic themes: record keeping, inappropriate risk assessment, communication and information sharing, failures to recognise the signs of abuse, and training. This list bears some remarkable similarities with that in Table 1 and is echoed in the work of Sharp-Jeffs and Kelly (2016). There are additional practice issues intimated in these findings. For example, the difficulties of securing the involvement of general practitioners (Doctors) (Sharp-Jeffs and Kelly 2016); few review processes are mandated to provide actionable recommendations (Bugeja et al. 2013); where they make recommendations there is a lack of a centralised response to them with the onus of responsibility placed on local areas to deliver (Home Office 2016); and there are dangers of co-option (Sheehy 2018: 374-5). As Sheehy (2018: 374) points out, feminist analysis not only puts women's deaths at the hands of men on a continuum of everyday violence(s), they also ask critical questions about who, what, why, and how, change may or may not occur. Questions such as these are frequently glossed by DHRs.

To summarise, the brief overview of policy responses to IPV/IPH outlined above suggests a range of policies and practices which have become, over time, locked into policy agendas internationally. This locked in presence has become particularly salient as a result of the increasing rapidity with which such policies now travel the globe (Goodmark 2015; Walklate and Fitz-Gibbon 2018). Further, this overview contains a number of additional messages. First, there has been an enormous amount of energy at every level devoted to changing policies and practices in relation to violence(s) against women, yet the global statistics in relation to deaths of women at the hands of men remains persistently consistent (UNODC 2013; CFOJA 2018; Femicide Census 2018). Within all of this activity, there have been undoubtedly some improvements made but research consistently indicates that more can be done. Second, much of the activity documented here, despite best efforts at multi-agency partnership working, information sharing, and so on, has proceeded on the back of research on violence against women which treats such violence as separate and separable from the recourse to violence more generally (Sechrist and Weil 2017). In this, criminology has been as complicit (qua 
Iratzoqui and McCutcheon 2018) in driving these kinds of policy agendas forward as much as those stakeholders (including feminists) with vested interests in them (qua Walklate 2008). Third, and implied by message two, responses to IPV/IPH have remained implicitly wedded to understanding of such events as preventable incidents rather than constituent elements of processes (Genn 1988; Brennan 2016; Sheehy 2018). Indeed, as has been intimated, it is important to remember that people's real lives are messy. They cannot be separated into discrete identifiable incidents. Moreover, organisational life is also messy and translating policy into practice is fraught with difficulties and potentialities for failure (see inter alia Lewis and Greene 1978). Taken together, they point to the obvious and inherent complexities involved in addressing IPV/IPH. So fourth, and following on from some of Sheehy's (2018) observations, given the rise in global interest in IPV/IPH, it is perhaps time to change the narrative on how policy responses to intimate partner homicide might better understood. The following discussion offers some suggestions on how this this might be achieved.

\section{Thinking Differently: Making a Space for Complexity Theory}

Complexity theory has been slow to penetrate the social sciences generally (Byrne 1998) and has perhaps been even slower to find a presence in criminology. Yet, as Walby (2007) has argued, it provides a useful toolkit with which to overcome some of the wellestablished theoretical and conceptual limitations associated with various 'systems' theories. In applying this toolkit, it is important to note that complexity theory has at its heart not just that human beings and systems are 'complex' but it also retains a commitment to appreciating the relationship between agency and structure as a duality. The key general propositions of complexity theory point to the difficulties in abstracting the whole from its parts since each system has, as its environment, all other systems. So, systems might link or interact with one another but one is not reducible to the other and the extent to which systems couple (work together or not) is an empirical one not a theoretical one. This non-reductionist whole systems emphasis shares some parallels with Liu's (2017) 'relationism'.

Relationism, Liu suggests, has at its centre Asian values of harmony, family, honour and holistic thinking. Holistic thinking involves 'an orientation to the context or field as a whole, including attention to relationships between a focal object and the field, and a preference for explaining and predicting events on the basis of such relationships' (Nisbett et al. 2001:93, quoted by Liu 2017: 30). This thinking is contrasted with the analytical thinking of Western societies which reflects a tendency towards prediction from decontextualized events (Liu: ibid). Given the capacity for criminal justice policies (and theories) to travel the globe, observations such as these are particularly pertinent to criminology especially given its embrace of risk and predictability. The values put to the fore by Liu (2017) are also pertinent to criminal justice policies addressing IPV/IPH since in cases such as these context really does matter (see inter alia Machado et al. 2010). To be explicit, in parallel with relationism, complexity theory centres the complex nature of human beings, the complex nature of systems, is non-reductionist and nonlinear, and is holistic in orientation. This kind of orientation has profound implications for criminology, its embrace of positivism and the criminal justice policies that flow from it, including policies on violence against women. At this juncture, the tensions between relational and analytical thinking (qua Liu) become manifest. 
Pycroft and Bartollas (2018: 4) state:

To understand the nature and behaviour of complex systems reductionist and positivist experimental methodologies reified by positivist approaches are ineffective, as when we abstract from the whole to the part, we can only understand the part and not the whole.

As these authors observe, such positivistic approaches have nothing meaningful to say about human agency. This is crucial to a wide range of policies, processes and practices, including the problems and possibilities of responding to violent relationships. For example, Pycroft and Bartollas (2018) make a compelling argument for understanding how historical practices in the criminal justice system have woven together concepts of utilitarian power in which risk assessment (particularly pertinent to the discussion here) has become locked in as measurable, doable activity on which action can be based. The implications of this are profound (see inter alia Mythen 2014; Walklate 2018). The question remains how this different way of thinking might contribute to changing the policy narrative in respect of policy responses to IPV/IPH.

Tolmie (personal communication) has proposed a model for creating system change in relation to the New Zealand mortality review committee (which also deals with IPH). This model embraces complexity in terms of the 'Cynefin' Framework (http://cognitive-edge. com/resources/glossary). However, this framework situates policy and practice securely in the realm of the knowable and in so doing it leads to policy responses that might 'nudge the system' towards change or 'mind the gap' between policy and practice both of which might be complex and/or complicated (Tolmie: personal communication). However, as Braithwaite and D'Costa (2018) point out, given the changing nature of social reality itself (the rising influence of the virtual world, see Harris 2018 on women's experiences of violence for example), any response relying on the 'knowable' has become increasingly problematic. Yet, this presumption of knowability and thereby predictability has risen up conceptual and policy agendas as risk has increasingly been seen as the 'master key' (Mythen 2014). The Cynefin model of complexity remains wedded to both knowability and predictability. Complexity theory demands, not that knowability and predictability are eschewed per se, but that they are put in their place. Indeed, Braithwaite and D'Costa (2018: 543) assert,

"Best practicitis" (Ramalingam 2013: 33) and evidence-based policy can be public policy curses. They indoctrinate private and public policymakers to persist with evidence-based policy when it is demonstrably failing in new contexts.

This 'best practicitis' is rooted in knowability and predictability and poses challenges for all travelling policies and particularly those relating to IPV/IPH (qua Goodmark 2015). However, using complexity theory to think relationally/holistically also poses challenges for policy agendas in situ. This requires further explanation.

Addressing a different issue (that of deterrence), Braithwaite (2018) proposes seven principles of crime prevention for minimally sufficient deterrence to be operative. Central to these principles is the concept of 'inexorability'. Following this principle, and for the concerns of this paper, violence is the problem. The recourse to violence and the consequences of violence are relentless at the global, regional, local and interpersonal levels. The principles Braithwaite (2018) develops are rooted in an appreciation of complexity theory in which knowability is not assumed. Like the good physician, Braithwaite and D'Costa (2018) argue, the willingness to probe in the face of the unknown is as equally essential to successful intervention on criminal behaviour as it is for the clinician. Inexorability embraces what is known and unknown: taken together, 
they might result in a successful intervention. Much in the realm of IPV/IPH is unknown and unknowable despite, for example, conceptual assumptions of violence escalation in relationships, the utility of risk assessment, and/or the efficacy of multi-agency partnerships. This is because since in essence, people and organisations are messy and/or unpredictable. They can, and do, often behave in ways other than expected. Complexity theory allows for this to be embraced. This means, not that the policies discussed here are terminated but that perpetual pre-occupation with them as separate and separable interventions from violence more generally is. It is at this juncture the (criminological) line of sight changes.

Sights need to be set on a holistic vision of violence against women as a constituent element of the recourse to violence more generally. Re-setting the line of vision affords a bigger picture for making sense of IPV/IPH to come into view. In this picture, the known (for example the high risks of lethal violence for women in the process of separation, and/or that IPV offenders commit other offences permitting targeted deterrence, Sechrist and Weil 2017), are set alongside the unknown (many women killed by their partners have had no contact with the criminal justice process neither have their partners), and are put alongside chaotic lives (the unpredictability of drugs, alcohol and mental illness as well documented factors contributing to violence). This framing reaches beyond the tensions of failing to recognise this violence as gendered (Westmarland and Kelly 2016). It also reaches beyond the facts highlighted by Sherman et al. (2017) though their evidence concerning the suicidal tendencies of domestic abuse perpetrators clearly has significant practice implications in relation to risk assessment (as in one of the cases cited above) and also significant implications for information sharing. Following Sherman et al. (2017), though with a different emphasis, debunking some of the myths surrounding violence against women is part of thinking differently about policy responses to this issue. Recognising the messiness of people's lives, which complexity theory permits, means taking on board the shame and stigma women may feel about the presence of violence in their lives (and/or drugs and alcohol) and the additional concerns such feelings generate about what might happen to their children post criminal justice involvement. Thinking about what women themselves want from criminal justice is also a good place to start.

\section{Conclusion}

Embracing complexity theory does not imply the policies discussed here are in and of themselves wrong or information sharing could not be improved, or risk assessments more nuanced, or women's voice better accounted for, and/or IPV be decriminalised (Goodmark 2018). However, it does suggest we view these policies and their potential not through a positivistic embrace of risk but through a conceptual agenda embracing complexity and holism. This might afford a better way to make sense of messy individual lives, messy organisational lives, and the complicity of criminology/ists, in devising responses to them. Listening to women's voices, their understandings of justice, and what they might want from criminal justice might be one place to (re)start (Goodmark 2017). However, this in itself is only one element of a bigger and more complex picture in understanding the recourse to violence (against women) by men (and sometimes women) across the globe which cuts across war, peace and post-conflict situations (Barberet 2014). 
Acknowledgements The empirical work from which this paper emanated was supported by funding from the Research Development Fund, School of Law and Social Justice, University of Liverpool. An earlier version of this paper was presented at a public seminar at Monash University in February 2018. The authors are grateful to the participants of that seminar for their feedback on this work.

Funding This work was supported by the Research Development Fund in the School of Law and Social Justice, University of Liverpool, U.K.

\section{Compliance with Ethical Standards}

All the data referred to has been anonymised in accordance with the ethical standards of the institutional and/or national research committee and with the 1964 Helsinki Declaration and its later amendments or comparable ethical standards.

Ethical Statement Informed consent was not applicable.

Conflict of Interest The authors declare that they have no conflict of interest.

Open Access This article is distributed under the terms of the Creative Commons Attribution 4.0 International License (http://creativecommons.org/licenses/by/4.0/), which permits unrestricted use, distribution, and reproduction in any medium, provided you give appropriate credit to the original author(s) and the source, provide a link to the Creative Commons license, and indicate if changes were made.

\section{References}

Australian Human Rights Commission (2016). A National System for domestic and family violence death review - December. Canberra.

Baker, D. (2016). Deaths after police contact: constructing accountability in the 21st century. London: PalgraveMacMillan.

Barberet, R. (2014). Women, crime, and criminal justice. London: Routledge.

Barlow, C., \& Walklate, S. (2018). Policing domestic violence: the golden thread of discretion. Policing: A Journal of Policy and Practice. Online first. https://doi.org/10.1093/police/pay001

Braithwaite, J. (2018). Minimally sufficient deterrence. Crime and Justice. Chicago: University of Chicago Press Downloaded from 132.174.250.101 on October 10, 2018.

Braithwaite, J., \& d'Costa, B. (2018). Cascades of violence: war and peace-building across South Asia. Australian National University: ANU press.

Braun, V., \& Clarke, V. (2006). Using thematic analysis in psychology. Qualitative Research in Psychology, 3(2), $77-101$.

Brennan, D. (2016). Femicide census profiles of women killed by men: redefining an isolated incident. London: Women's Aid.

Bridger, E., Strang, H., Parkinson, J., \& Sherman, L. W. (2017). Intimate partner homicide in England and Wales 2011-2013: pathways to prediction from multi-agency domestic homicide reviews. Cambridge Journal of Evidence Based Policing, 1, 93-104. https://doi.org/10.1007/s41887-017-0013-z.

Bugeja, L., Butler, A., Buxton, E., Ehrat, H., Hayes, M., McIntyre, S., \& Walsh, C. (2013). The implementation of domestic violence death reviews in Australia. Homicide Studies, 17(4), 353-374.

Byrne, D. (1998). Complexity theory and the social sciences: an introduction. London: Taylor and Francis.

Canadian Domestic Homicide Prevention Initiative (CDHPI) (2016). Domestic violence death review committees: "Speaking for the Dead to Protect the Living" May. www.cdhpi.ca. Accessed 1/05/2017

Canadian Femicide Observatory for Justice and Accountability (CFOJA) (2018). 106 women and girls killed by violence: Eight Month Report. https://www.femicideincanada.ca. Accessed 11/09/2018

Carrington, K., \& Hogg, R. (2017). Deconstructing criminology's origin stories. Asian Journal of Criminology online first, 12, 181-197. https://doi.org/10.1007/s11417-017-9248-7.

Corradi, C., \& Stokl, H. (2014). Intimate partner homicide in 10 European countries: statistical data and policy development in a cross-national perspective. European Journal of Criminology, 11(5), 601-618. 
Cunneen, C. (2014). Access to justice for aboriginal people in the Northern Territory. Australian Journal of Social Issues, 49(4), 219-242.

Cunneen, C., \& Rowe, S. (2015). Decolonising indigenous victimisation. In D. Wilson \& S. Ross (Eds.), Crime, Victims and Policy: International Contexts, Local Experiences (pp. 10-32). London: Palgrave-MacMillan.

Curtis, F., Shepherd, J., Brennan, I., \& Simon, T. (2011). Effectiveness of anonymised information sharing and use in health service, police, and local government partnership for preventing violence related injury: experimental study and time series analysis. BMJ, 342, d3313. https://doi.org/10.1136/bmj.d3313 (Published 16 June 2011).

Cussen, T., \& Bryant, W. (2015). Domestic/family homicide in Australia. Research in Practice no. 38. Canberra: Australian Institute of Criminology.

Dawson, M. (2016). Punishing femicide: criminal justice responses to the killing of women over four decades. Current Sociology, 64(7), 996-1016.

Dawson, M. (2017). Domestic homicide reviews: an international perspective. London: MacMillan-Palgrave.

Day, A., Richardson, T., Bowen, E., \& Bernardi, J. (2014). Intimate partner violence in prisoners: toward effective assessment and intervention. Aggression and Violent Behavior, 19, 579-583.

De Avila, T. P. (2018). The criminalisation of femicide. In K. Fitz-Gibbon, S. Walklate, J. McCulloch, \& J. M. Maher (Eds.), Intimate partner violence, risk and security: securing women's lives (pp. 181-198). London: Routledge.

De Sousa Santos, B. (2014). Epistemologies of the south: justice against epistemicide. London: Routledge.

DeKeseredy, W. S., Dragiewicz, M., \& Schwartz, M. D. (2017). Abusive endings: separation and divorce violence against women. Oakland: University of California Press.

Eguizábal, C., Ingram, M., Curtis, K. M., Korthuis, A., Olson, E. L., Phillips, N. (2016). Crime and violence in central America's Northern Triangle. http://www.wilsoncenter.org/lap. Accessed 1/06/2017

Femicide Census (2018). The Femicide Census: 2017 findings. http://www.femicidecensus.org.uk. Accessed 12 /01/2019

Fitz-Gibbon, K. (2016). 2015 Churchill Fellowship Report: The Peter Mitchell Churchill Fellowship to examine innovative legal responses to intimate homicide in the UK, USA, Canada. Canberra ACT Australia: The Winston Churchill Memorial Trust.

Fitz-Gibbon, K., \& Walklate, S. (2017). The efficacy of Clare's law in domestic violence law reform in England and Wales. Criminology \& Criminal Justice, 17(3), 284-300.

Fitz-Gibbon, K., Walklate, S., McCulloch, J., \& Maher, J. M. (Eds.). (2018). Intimate partner violence, risk and security: securing women's lives. London: Routledge.

Genn, H. (1988). Multiple victimisation. In M. Maguire \& J. Ponting (Eds.), Victims of crime: a new deal? (pp. 88-98). Buckingham: Open University Press.

Goodmark, L. (2015). Exporting without license: the American attempt to end intimate partner abuse worldwide. In R. Goel \& L. Goodmark (Eds.), Comparative Perspectives on Gender Violence: Lessons from Efforts Worldwide (pp. 3-14). Oxford: Oxford University Press.

Goodmark, L. (2017). Justice as a tertiary prevention strategy. In C. M. Renzetti, D. R. Follingstad, \& A. L. Coker (Eds.), Preventing intimate partner violence: Interdisciplinary perspectives (pp. 185-208). Bristol: Policy Press.

Goodmark, L. (2018). Decriminalizing domestic violence. Oakland: University of California Press.

Gray, I. (2016). Findings into death with inquest of Kelly Ann Thompson. Coroner's Court at Melbourne, 21 April. Available at http://www.coronerscourt.vic.gov.au/resources/5ffa0a31-91fa-4e58-a0af-ce4a6c23d6f0 /kellyannthompson_082414.pdf. Accessed 11 July 2016.

Harris, B. (2018). Spacelessness, spatiality, and intimate partner violence; technology-facilitated abuse, stalking and justice. In K. Fitz-Gibbon, S. Walklate, J. McCulloch, \& J. M. Maher (Eds.), Intimate partner violence, risk and security: securing women's lives (pp. 52-70). London: Routledge.

Hirschel, D., Buzawa, E., Pattavina, A., \& Faggiani, D. (2007). Domestic violence and mandatory arrest laws: to what extent do they influence police arrest decisions? Journal of Law and Criminology, 98, 255-298.

Home Office. (2016). Domestic homicide reviews: key findings from analysis of domestic homicide reviews. London: Home Office.

Iratzoqui, A., \& McCutcheon, J. (2018). The influence of domestic violence in homicide cases. Homicide Studies, 22(2), 145-160.

Johnson, H., Eriksson, L., Mazarolle, P., \& Wortley, R. (2017). Intimate partner femicide: the role of coercive control. Feminist Criminology online first, 14, 3-23. https://doi.org/10.1177/1557085117701574.

Kirkwood, C. (1993). Leaving abusive partners. London: Sage.

Lewis, R., \& Greene, J. R. (1978). Implementation evaluation: a future direction in project evaluation. Journal of Criminal Justice, 6, 167-176.

Liu, J. (2017). The new Asian paradigm: a relational approach. In J. Liu, M. Travers, \& L. Chang (Eds.), Comparative criminology in Asia (pp. 17-32). Switzerland: Springer. 
Machado, C., Dias, A., \& Coehlo, C. (2010). Culture and wife abuse: an overview of theory, research and practice. In S. G. Shoham, P. Knepper, \& M. Kett (Eds.), International handbook of victimology (pp. 639668). Boca Raton: CRC Press.

McCulloch, J., Maher, J. M., Fitz-Gibbon, K., Segrave, M., \& Roffee, J. (2016). Review of the family violence risk assessment and management framework (CRAF) final report. www.monash.edu Melbourne. Accessed $31 / 05 / 2016$

Medina, A. J., Robinson, A., \& Myhill, A. (2016). Cheaper, faster, better: expectations and achievements in police risk assessment of domestic abuse. Policing. Advance access. https://doi.org/10.1093/police/paw023.

Myhill, A., \& Hohl, K. (2016). The "golden thread": coercive control and risk assessment for domestic violence. Journal of Interpersonal Violence. https://doi.org/10.1177/0886260516675464.

Mythen, G. (2014). Understanding the risk society. London: Palgrave.

O’Malley, P. (2006). Criminology and risk. In G. Mythen \& S. Walklate (Eds.), Beyond the risk society (pp. 4358). London: McGraw-Hill.

Percy, K. (2015). Kelly Thompson murder inquest: police did not respond to neighbour's concerns about intervention order breach, coroner told. ABC News, 18 June.

Pycroft, A., \& Bartollas (2018). Forgiveness as potentiality in criminal justice. Critical Criminology. https://doi. org/10.1007/s10612-017-9383-6

Regoecz, W., \& Hubbard, D. (2018). The impact of specialized domestic violence units on case processing. American Journal of Criminal Justice, 43, 570-590. https://doi.org/10.1007/s12103-018-9435-9.

Robinson, A. L. (2006). Reducing repeat victimisation among high-risk victims of domestic violence: the benefits of a coordinated community response in Cardiff, Wales. Violence Against Women, 12(8), 761788. https://doi.org/10.1177/1077801206291477.

Sechrist, S. M., \& Weil, J. D. (2017). Assessing the impact of a focused deterrence strategy to combat intimate partner domestic violence. Violence Against Women, 24(3), 243-265.

Segrave, M., Wilson, D., \& Fitz-Gibbon, K. (2016). Policing intimate partner violence in Victoria (Australia): examining police attitudes and the potential of specialisation. Australian and New Zealand Journal of Criminology., 51, 99-116. https://doi.org/10.1177/0004865816679686.

Sharp-Jeffs, N., \& Kelly, L. (2016). Domestic homicide review (DHR) case analysis report for standing together. London: London Metropolitan University-Standing Together.

Sheehy, L. (2018). A feminist reflection on domestic violence death review. In M. Dawson (Ed.), Domestic homicide reviews: an international perspective (pp. 373-402). London: MacMillan-Palgrave.

Shepard, M. F., Falk, D. R., \& Elliott, B. A. (2002). Enhancing coordinated community responses to reduce recidivism in cases of domestic violence. Journal of Interpersonal Violence, 17(5), 551-569.

Sherman, L., \& Berk, R. (1984). The specific deterrent effect of arrest for domestic assault. American Sociological Review, 49(2), 261-276.

Sherman, L. W., Schmidt, J. D., Rogan, D. P., et al. (1991). From initial deterrence to long-term escalation: short custody arrest for ghetto poverty violence. Criminology, 29(4), 821-849. https://doi.org/10.1111/j.17459125.1991.tb01089.x.

Sherman, L., Strang, H., \& O’Connor, D. (2017). Introduction: key facts about domestic abuse- lessons from eight studies. Cambridge Journal of Evidence Based Policing, 1, 59-63.

Smith, P. H., Murray, C. E., \& Coker, A. L. (2010). The coping window: a contextual understanding of the methods women use to cope with battering. Violence and Victims, 25(1), 18-28.

Smith, S. G., Fowler, K. A., \& Niolon, P. H. (2014). Intimate partner homicide and corollary victims in 16 states: National Violent Death Reporting System, 2003-2009. American Journal of Public Health, 104(3), 461466.

Stanko, E. A. (1995). Policing domestic violence: dilemmas and contradictions. Australian and New Zealand Journal of Criminology, 28(Suppl. 1, 31-44.

Stanley, N., \& Humphreys, C. (2014). Multi-agency risk assessment and management for children and families experiencing domestic violence. Children and Youth Services Review, 47(1), 78-85.

Star, S., \& Griesemar, J. (1989). Institutional ecology, translations and boundary objects: amateurs and professionals in Berkeley's Museum of Vertebrate Zoology 1907-1939. Social Studies of Science, 19, 387-342.

Thompson, K. (2013). Multi-agency information practices in children's services: the metaphorical 'jigsaw' and professionals quest for the full picture. Child and Family Social Work, 18(2), 189-197.

Thornton, S. (2017). Police attempts to predict domestic murder and serious assaults: is early warning possible yet? Cambridge Journal of Evidence Based Policing, 1, 64-80. https://doi.org/10.1007/s41887-017-0011-1.

United Nations Office on Drugs and Crime (UNOCD) (2013) Global study on homicide 2013. UNITED NATIONS PUBLICATION Sales No. 14.IV.1 eISBN: 978-92-1-054205-0.

Walby, S. (2007). Complexity theory, systems theory, and multiple intersecting social inequalities. Philosophy of the Social Sciences, 37(4), 449-470. 
Walby, S., Towers, J., Balderston, S., Corradi, C., Francis, B., Heiskanen, M., Helweg-Larsen, K., Mergaert, L., Olive, P., Palmer, E., Stöckl, H., \& Strid, S. (2017). The concept and measurement of violence against women and men. Bristol: Policy Press.

Walklate, S. (2008). What is to be done about violence against women? Gender, violence, cosmopolitanism and the law. British Journal of Criminology, 48(1), 39-54.

Walklate, S. (2018). Criminology, gender and risk: the dilemmas of northern theorising for southern responses to intimate partner violence. International Journal for Crime, Justice and Social Democracy, 7(1), 1-14. https://doi.org/10.5204/ijcjsd.v7i1.444.

Walklate, S., \& Fitz-Gibbon, K. (2018). The violence of 'northern' theorising for policy responses to intimate partner violence. In K. Carrington, M. Sozzo, R. Hogg, \& J. Scott (Eds.), Palgrave handbook on criminology and the global south (pp. 847-866). London: Palgrave.

Westmarland, N. (2011). Co-ordinating responses to domestic violence. In J. Brown \& S. Walklate (Eds.), Handbook of sexual violence (pp. 287-307). London: Routledge-Willan.

Westmarland, L., \& Kelly, L. (2016). Domestic violence: the increasing tensions between experience, theory, research, policy and practice. In R. Matthews (Ed.), What is to be done about crime and punishment (pp. 3155). London: Sage.

World Health Organization (2013). Global and regional estimates of violence against women: prevalence and health effects of intimate partner violence and non-partner sexual violence. World Health Organization.

Publisher's Note Springer Nature remains neutral with regard to jurisdictional claims in published maps and institutional affiliations. 